\title{
服部 浩京都市
}

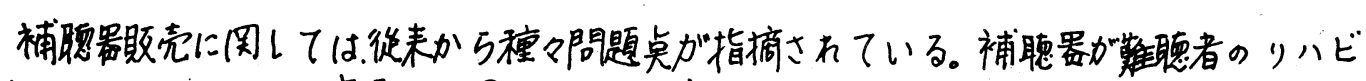

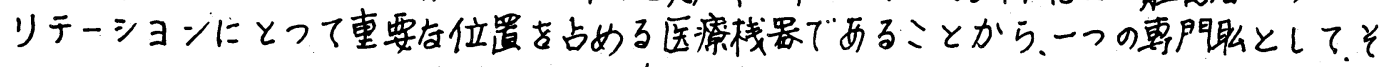
れにふさわいい知䧕技能を修得した者に資格を与えるような法制化さ行うべきであるが， 目下のところは、差し当り自主認定制の方向へ進んでいる。即与1987年補㯖罢さ含む。

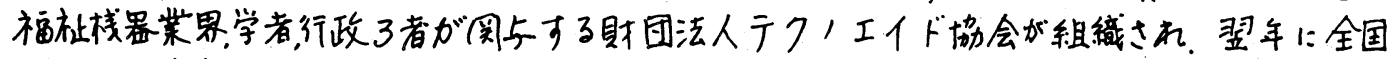

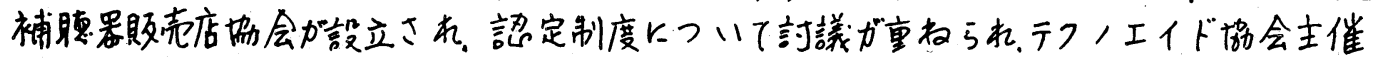

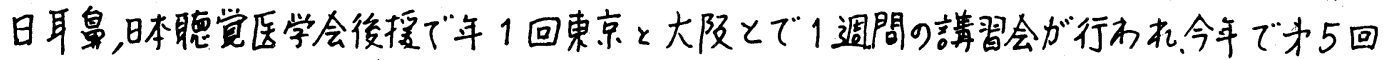
が終了している。更講習会修了后，更に3年以上の実務经验者の中が、1993年末に。

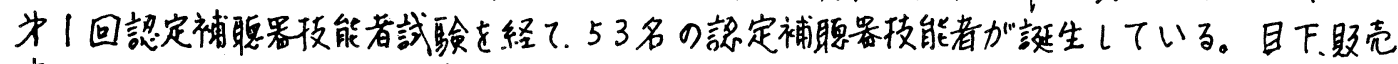

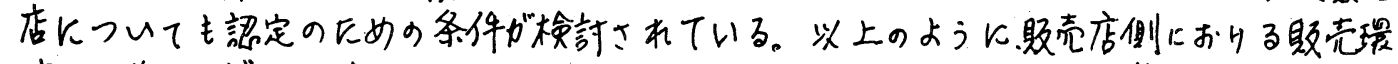

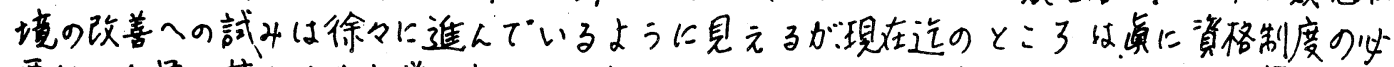

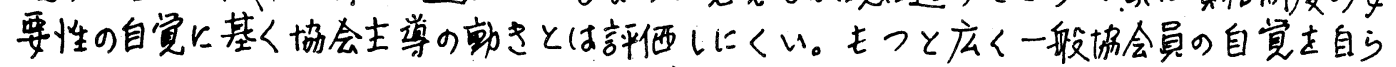

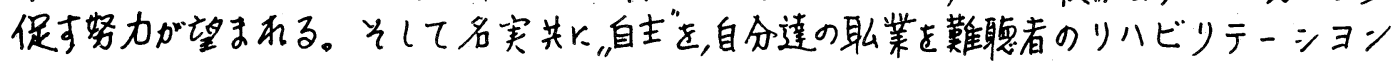
の一角を担うものだという誇りを持てるよう、自分建がま体とほつてやれる实力を備える妿 力を裏わてもらいたい。

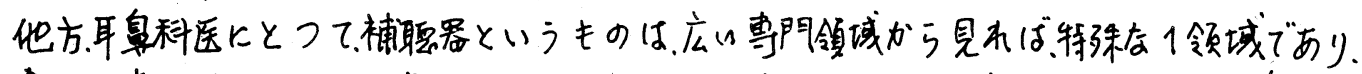

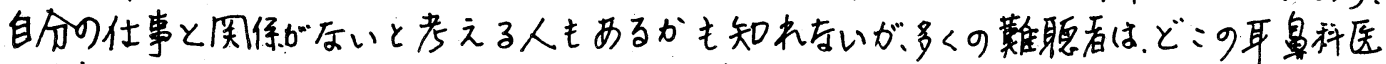

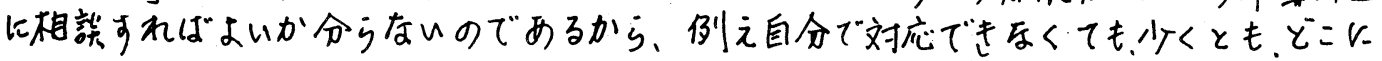
行くベきかという具体的なインホーメイショノを夫可地域において与えうれるように日

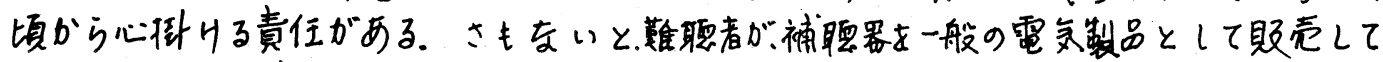
いる所で直接以䝼入する場合が多い現状をいつ迄も続けさせることにつながるからである。

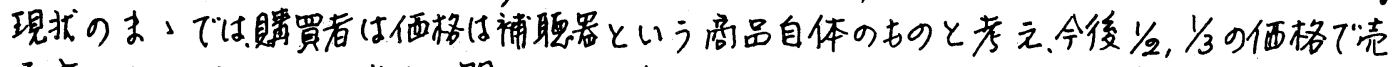

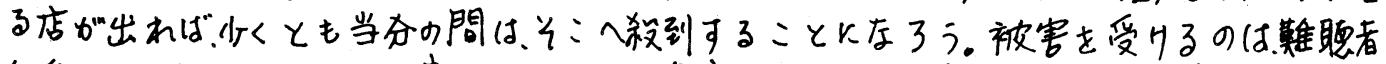

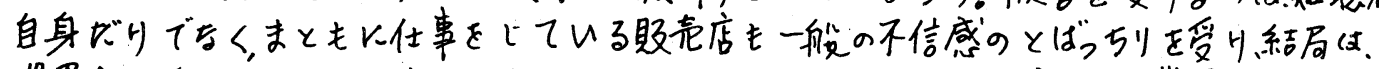

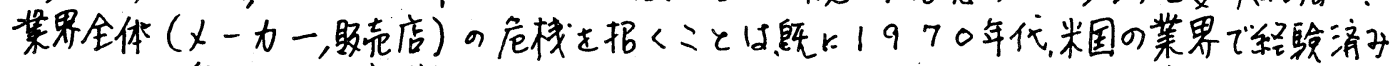

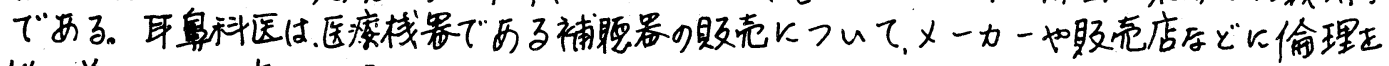
設く前に自らの責任を果さねばならちい。

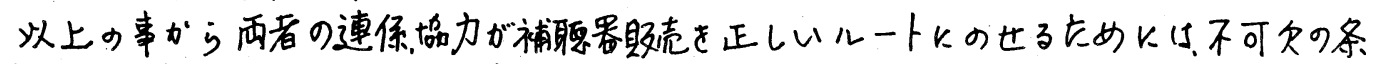

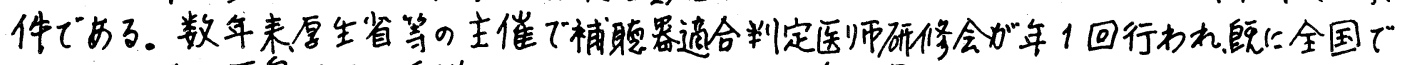

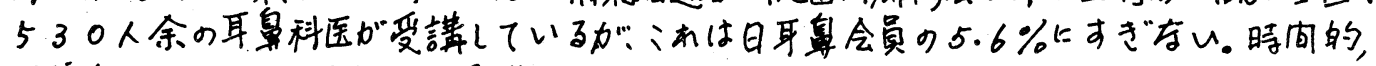

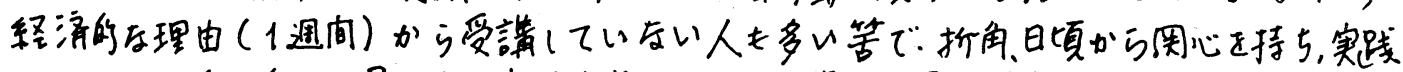
をしている人が参加し易いよう、方法を考元るできである。最近補㯖界相联，管理の地城体制

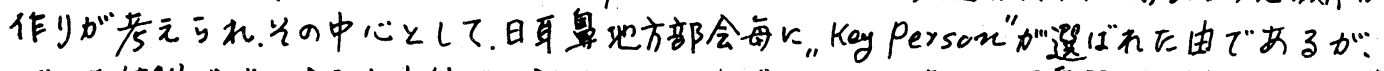

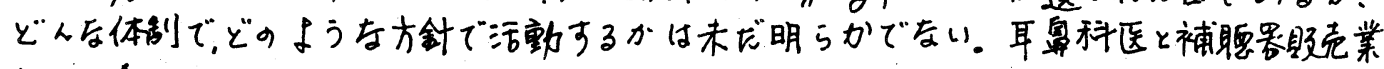

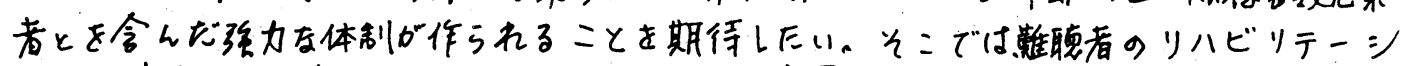
ヨンが建前でなく、共通の目的となることを両者の全员が明磄に認諴しな山ればをらをい。 
四1.1両者の協力周係の理实の一端を物語るーつの资料である。この状況を改善する ため长は、何をなすべきか，耳鼻科医各位が自ら問うていたうければ埇である。

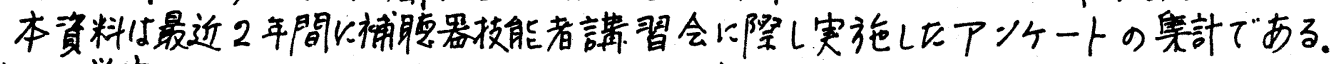
決して誉密な数值ではをいが. 大局さ知るには充分なものと考えている。

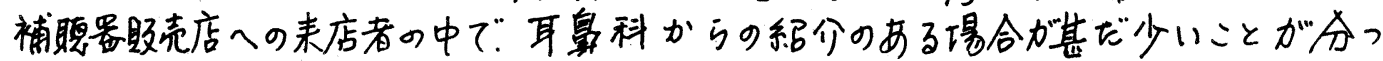
てもらえると思う。

最后的，瑅在の禣腹器供給の地城体制作りによつて医师と補腰券技能者との

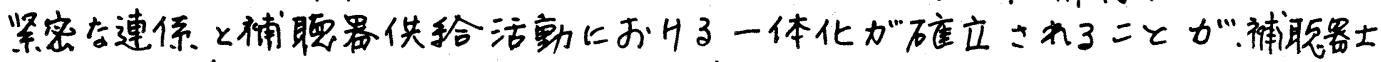
という国家资格が法制化されるための重要な条件となることを䛱䧕して進を べきことを捨記しなりればならない。

図1.

未店者の中で耳鼻科医の紹介のある割合(\%)

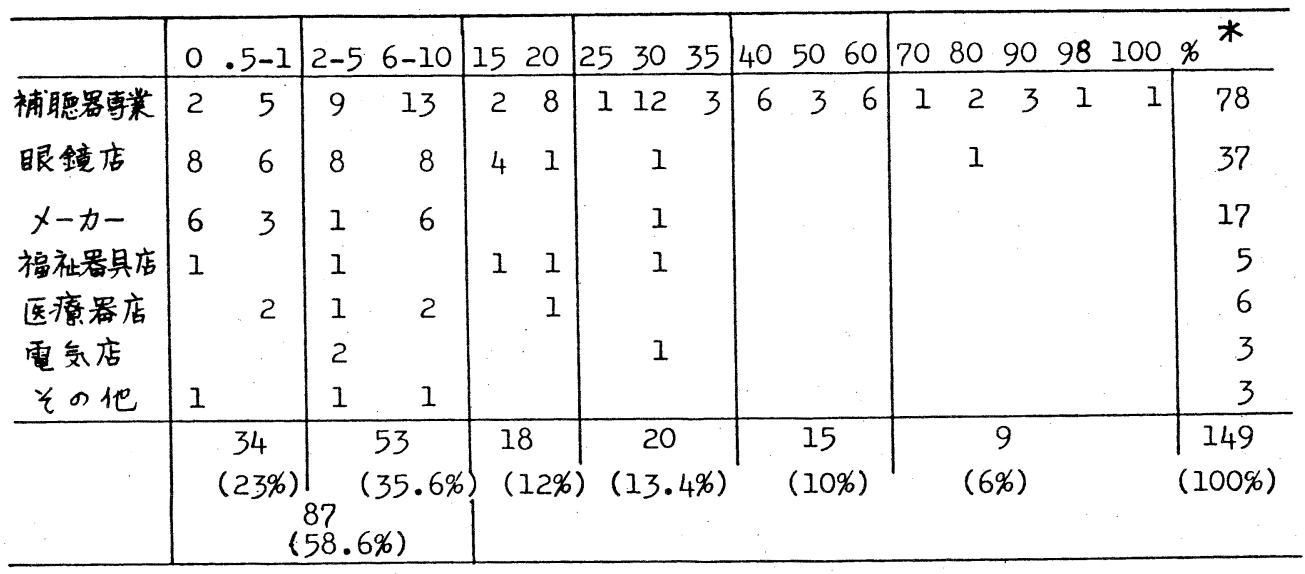

表中の数字は店の数を示す 